Hernán Iván Hurtado Castro

\title{
Coricancha como artefacto de poder inca y un lugar sagrado como [proto] museo
}

\section{Coricancha as an artifact of Inca power and a sacred place as a [proto] museum}

\author{
Hernán Iván Hurtado Castro \\ Universidad Nacional Mayor de San Marcos \\ hernanivanh@gmail.com
}

Fecha de recepción: 10 de diciembre de 2019

Fecha de aprobación: 20 de marzo de 2020

\section{Resumen}

Este artículo pretende llevar a cabo un examen liminal de una función de museo adherente que tuvieron los grandes lugares sagrados/ceremoniales, como fue el caso del Coricancha, también llamado Templo del Sol. Esto podría ser el desarrollo de un artefacto de poder dentro del Estado inca en expansión. Basamos esta propuesta en una relectura de las crónicas de los siglos XVI y XVII, junto con un enfoque arqueológico sobre el paisaje y lugares sagrados prehispánicos.

Palabras clave: Artefacto de poder, Museo, Coricancha, Inca, lugar sagrado.

\begin{abstract}
This paper aims to carry out a liminal examination of an adherent museum function that the great sacred/ceremonial sites had, as was the case of the Coricancha, also called Temple of the Sun. This could be the development of an artifact of power within the State Inca in expansion. We base this proposal on a rereading of the chronicles of the 16th and 17 th centuries together with an archaeological approach to the landscape and prehispanic sacred places.
\end{abstract}

Keywords: Artifact of power, Museum, Coricancha, Inca, sacred place. 


\section{Introducción}

En el presente trabajo analizaremos cómo algunas instituciones, sean de enseñanza, religiosas, etc., han estado vinculadas a proto ideas y preformas de museos como artefactos de poder. Este enunciado se ha hecho visible en los casos que presentó el trabajo de Soledad Pérez Mateo ${ }^{1}$, quien realiza un estudio sobre las academias y sus colecciones, tales como la Academia de Lasa, 2000 a. C., en Mesopotamia; y la Escuela de Ur, 5300 a. C. De ese mismo modo, otras instituciones o entidades tuvieron tendencias a desarrollarse como artefactos de poder en un marco museístico, entre ellos los castillos de la Europa feudal, los primeros bancos occidentales de finales del siglo XVI y sus formas de acopiar y mercadear obras de arte; el Berenberg Bank, fundado en 1590; las empresas con la revolución industrial y, finalmente, los edificios de propiedad de la Iglesia católica apostólica y romana desde el pontificado del papa Gregorio XIII.

Otro aspecto para destacar es que, a pesar de que los actuales marcos legales de guerra y conflictos armados consideran válidos los trofeos de guerra ${ }^{2}$, la concepción de este se remonta a los primeros conflictos sociales en las sociedades tempranas. De esa forma, se destaca la presencia de Alejandro Magno en Egipto, quien en su desarrollo expansionista y militar creó, en Alejandría, un artefacto de poder museístico, una institución occidental para la conservación y exhibición de objetos — por ejemplo, trofeos de guerra y ofrendas - como parte fáctica del discurso ideológico del vencedor, que admite y presea lo que está en el diseño de su nuevo territorio y paisaje social. Dicha institución es conocida como el Museion, que fue engrandecida por Ptolomeo, hijo de Alejandro.

Por último, por extensión antrópica, sucedió de similar forma con los lugares sagrados que encontró la expansión de la administración española en el naciente virreinato peruano. Huelgan ejemplos de una re funcionalización española en lugares sagrados que previamente fueron intervenidos por los incas: la reducción de Hatunqolla, la iglesia de Santo Domingo o Coricancha en Cuzco, las iglesias de Chincheros y San Juan Bautista en Huaytará, dispuesta sobre una estructura inca ${ }^{3}$.

La elaboración del presente ensayo se inscribe dentro de la teoría del poder y comunicación, a través del uso del concepto artefacto de poder. En ese sentido, fortalecemos nuestra propuesta con la revisión de investigaciones arqueológicas que se enfocan en el estudio del paisaje de lugares sagrados incas, así como la revisión de

$1 \quad$ Soledad Pérez Mateo, "La educación en los museos universitarios", Boletín de arte 25 (2018): 491-518.

2 Luis Bobadilla, Camilo Cammás y Nicole Solis, "Aproximaciones al derecho de los conflictos armados: de los trofeos e indemnizaciones de guerra" (tesis de licenciatura, Universidad de Chile, 2001). http:// repositorio.uchile.cl/handle/2250/111043.

3 Steven Wernke, "La producción de poder en el entorno construido a través de la invasión española, valle del Colca (Perú)", Boletín de Arqueología PUCP 20 (2016): 165. 
crónicas de los siglos XVI y XVII. Asimismo, empleamos las propuestas teóricas de Foucault y Luhmann ${ }^{4}$ sobre el poder y la comunicación, las cuales señalan que los constructos materiales específicos contribuyen de forma asertiva a la existencia de una relación vinculante de poder y subalternidad entre una persona y otras, por ejemplo, las escuelas, las leyes e instituciones de coerción. Pero también un lugar sagrado, con su dinámica propia, permite erigir una estructura de poder y control ideológico, de tal forma que un lugar sagrado como el Coricancha se legitimó y se hizo efectiva la sofisticación de su ejercicio ceremonial y uso social. El Coricancha fue, entonces, un artefacto de poder que permitió una caracterización material, entendible, vehiculizante y contundente de subalternidad en términos de poder.

Figura 1. Esquema del altar principal del Coricancha.

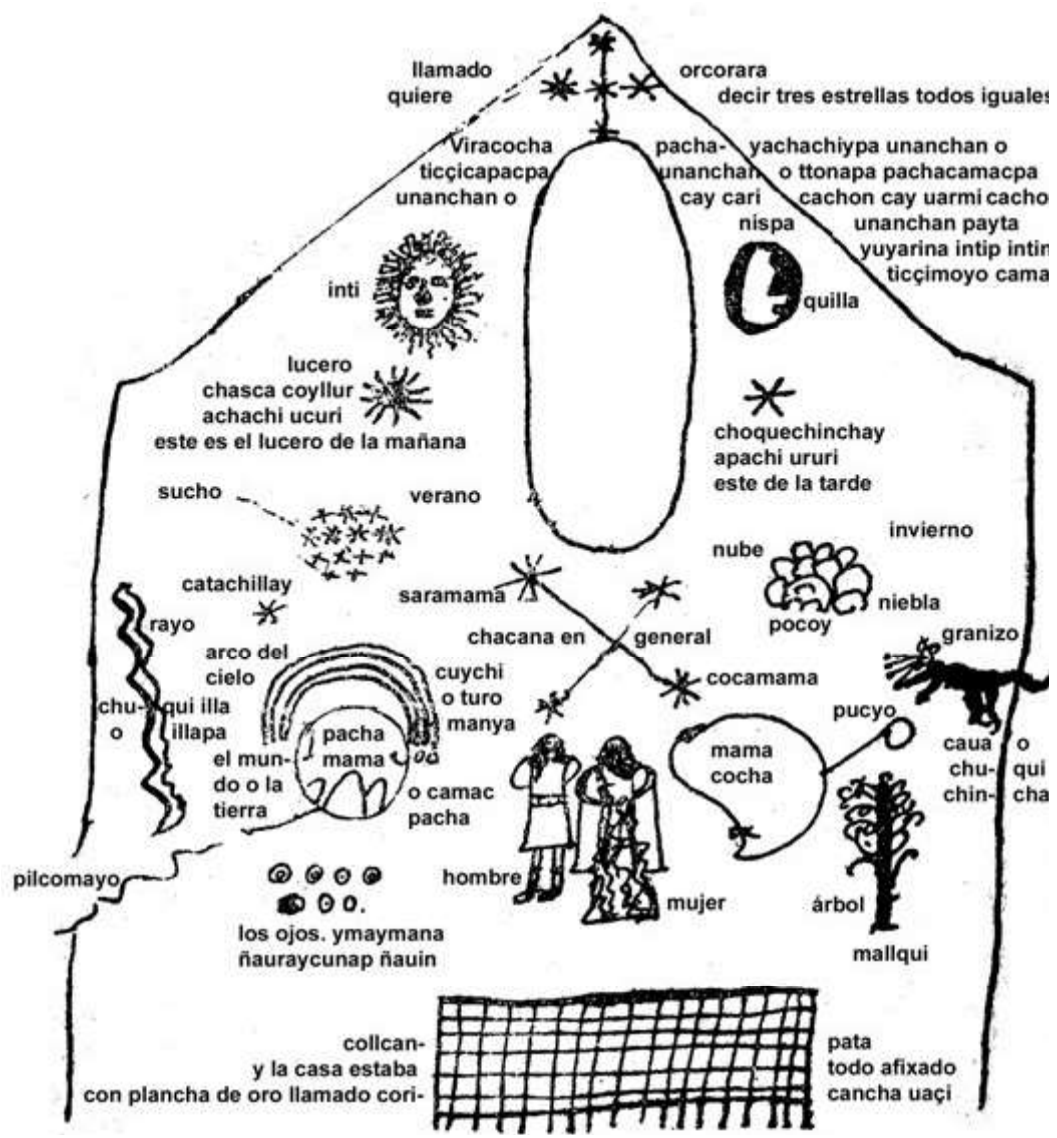

Fuente: Juan Santa Cruz Pachacuti, Relación de Antigüedades de este del reino del Pirú [1613] (Biblioteca Nacional de España, 1995), 147; José Elías, "El dibujo del Altar Mayor del Coricancha", Arte y Diseño A\&D 2 (2013): 14-18. Luhmann”, Politica y Sociedad 50, no. 3 (2013): 959-980. 


\section{Sobre lo que dan noticia las crónicas del Coricancha}

En diversos relatos los cronistas nos explican la importancia sagrada que ostentó el Coricancha, el cual fue denominado como un lugar excepcional y el más importante dentro del Estado que había sido conquistado por los españoles. Pedro Cieza de León nos relata que cuando la avanzada española se encontraba en Cajamarca, se tenían noticias de la existencia del Coricancha como un lugar de gran riqueza ${ }^{5}$. Además de su importancia simbólica, se encontraron en sus interiores una gran presentación de láminas y figuras de oro y plata. Por otro lado, mediante los registros de los cronistas del siglo XVI, se conoce que en el Perú existieron los Yachaywasi o "Casa del Saber"6. Dicho lugar fue una suerte de universidad profana, desde la óptica eclesiástica, donde se establecieron ciertas funciones de enseñanza y sentido de la conservación y exposición de la historia y artefactos suntuosos, entre ellos orfebrería, platería y otros.

Por ejemplo, Juan de Betanzos ${ }^{7}$, quien acompañó a Francisco Pizarro en su ingreso al Cusco el 15 de noviembre de 1533, nos presentó diversas biografías de los gobernantes incas y, podríamos decir, fue un proto etnógrafo de las prácticas ceremoniales en el Cusco y de otras costumbres del antiguo Perú, de manera que nuestro cronista fue testigo de cómo al Templo del Sol fue re funcionalizado y pasó a ser el Convento de Santo Domingo. También en su crónica rescató el mito de origen de los incas y señaló a Manco Cápac como fundador del Coricancha, realzando el mito de

$5 \quad$ "Y es público entre todos los indios ser este templo tan antiguo como la misma ciudad del Cuzco, más que Inga Yupangue, hijo de Viracoche Inga, lo acrecentó en riquezas y paró tal como estaba cuando los cristianos entraron en el Perú y lo más del tesoro fue llevado a Caxamalca por el rescate de Atahualpa, como en su lugar contaremos. Y dicen los orejones que después de haber pasado la dudosa guerra que tuvieron los vecinos del Cuzco con las chancas, que ahora son señores de la provincia de Andaguaylas, que como de aquella victoria que de ellos tuvieron quedase Inga Yupangue tan estimado y nombrado, de todas partes acudían señores a le servir haciéndole las provincias grandes servicios de metales de oro y plata, porque en aquellos tiempos había grandes mineros y vetas riquísimas. Y viéndose tan rico y poderoso, acordó de ennoblecer la casa del Sol, que en su lengua llaman 'Yndeguaxi' y por otro nombre la llamaban 'Curicancha' que quiere decir 'cercado de oro' y acrecentarla con riqueza. Y porque todos los que esto vieren o leyeren acaben de conocer cuán rico fue el templo que hubo en el Cuzco y el valor de los que lo edificaron y en él hicieron tan grandes cosas, pondré aquí la manera de él, según lo que yo vi e oí a muchos de los primeros cristianos que oyeron a los tres que vinieron desde Caxamalca, que [le] habían visto, aunque los indios cuentan tanto de ello y tan verdadero que no es menester otra probanza.”. Pedro Cieza de León, Crónica del Perú. El señorío de los Incas (Caracas: Biblioteca Ayacucho, 2005), 359-360. http://www.biblioteca.org.ar/libros/211665.pdf.

6 Garcilaso de la Vega, Comentarios Reales de los Incas (Lisboa: Princeps de Lisboa, 1609), 357. http:// shemer.mslib.huji.ac.il/lib/W/ebooks/001531300.pdf; Martín de Murúa, Historia general del Perú. Origen y descendencia de los Incas [1616] (Madrid: Imp. De don Arturo Góngora. 1962), 43.

$7 \quad$ "Y el Mango Capac agradescióselo, y paresciéndole bien el sitio y asiento do agora es en esta ciudad del Cuzco la casa y convento de Santo Domingo, que antes solia ser la Casa del Sol, como adelante la historia lo dirá, hizo allí el Mango Capac y su compañero, y con el ayuda de las cuatro mujeres, una casa, sin consentir que gente Alcaviza les ayudase, aunque los querian ayudar; en la cual casa se metieron ellos dos y sus cuatro mujeres". Juan de Betanzos, Suma y narración de los Incas (Madrid: Biblioteca Hispano-Ultramarina, 1880), 43. 
la semilla traída de la cueva nominada Pacaritambo para sembrar en los jardines del edificio. Asimismo, Juan de Betanzos señala que fue el Inca Pachacútec el constructor del Templo del Sol${ }^{8}$. Si bien la crónica de Betanzos es vital para entender cuál fue la visión del conquistador en el momento inicial de la conquista, nos queda claro que intentó moldear ese nuevo espacio a su visión del mundo. Por eso, terminó equiparando el mundo andino a su visión cristiana, donde existe la idea de dios creador, identificando a Viracocha o Pachamama como tal.

Otro testimonio importante fue el relatado por el inca Garcilaso de la Vega ${ }^{9}$, quien manifestó que el inca Manco Cápac les quitó el ídolo y sus tradiciones a los Cauiña ${ }^{10}$. Sin embargo, no sabemos si este ídolo fue destruido o confinado a un espacio común, como lo era un altar de deidades o huacas ${ }^{11}$. Un ejemplo fue la huaca Cusicancha, considerada la primera que cumplió tal función. Incluso se afirma que el inca Túpac Yupanqui habría nacido ahí, o quizá fue incluido en uno de los ceques, que eran rayas ceremoniales que tenían como punto de partida el centro del mismo Coricancha, y a su vez contaban con un correlato de 323 huacas dispuestas y distribuidas en los 41 ceques. No obstante, podemos pensar que existieron conductas recurrentes de acumulación de prendas o trofeos de guerra, que, para efectos de ilustrar lo que estuvo pasando en un tiempo prehispánico, los incas habrían acumulado en un muestrario los ídolos del vasto territorio tahuantinsuyano.

Entre tanto, Juan Santa Cruz Pachacuti realizó una valoración especial sobre el Coricancha, destacando su registro etnográfico sobre costumbres e instituciones que se estarían extinguiendo por la victoria religiosa y política que el dios judeocristiano infringió a las huacas e ídolos andinos. Es así como explica que en el Coricancha existían diversos artefactos, expresando "[...] que aquí los pintaré como estaban puestos hasta que entró a este reyno el santo Ebangeleo"12. De esta forma, el cronista Pachacuti realizó un esquema cosmogónico (ver figura 1) que refiere a la imagen principal del edificio y que representó un ordenamiento social, político, religioso y territorial.

Por último, Santa Cruz Pachacuti, en el mismo sentido y coincidencia con sus contemporáneos, le atribuyó historia, sacralidad y alta jerarquía al Coricancha, de forma similar a un trofeo de guerra, que suele ser el corolario de algún conflicto y a su

$8 \quad$ Ibid., 64-65.

$9 \quad$ Garcilaso de la Vega, Comentarios Reales de los Incas.

10 "Esta nación Cauiña se preciaba, en su vana creencia, que sus primeros padres habían salido de una laguna, adonde decían que volvían las ánimas de los que morían, y que de allí volvían a salir y entraban en los cuerpos de los que nacían. Tuvieron un ídolo de espantable figura a quien hacían sacrificios muy bárbaros. El Inca Manco Cápac les quitó los sacrificios y el ídolo, y les mandó adorar al Sol, como a los demás sus vasallos". Ibid., 57.

11 John Rowe, "La constitución inca del Cuzco", Histórica 9, no. 1 (1985): 87.

12 Juan Santa Cruz Pachacuti, Relación de Antigüedades de este del reino del Pirú [1613], (Biblioteca Nacional de España, 1995), 227. http://www.bne.es/es/Actividades/Exposiciones/Exposiciones/ exposiciones2016/BibliotecaIncaGarcilasoSeleccion/obra09.html. 
vez instrumento de paz entre vencedores y vencidos ${ }^{13}$. Podríamos, entonces, afirmar que existió una conducta política recurrente — con sus propias lógicas sociales - que buscó, a través de la utilización de símbolos u objetos simbólicos, ejercer el control de nuevos espacios conquistados. Es decir, cada parte integrada al nuevo Tahuantinsuyo debía estar representada. Se buscaba la integración que permitiera ejercer un mejor control de las nuevas provincias conquistadas y no siempre la destrucción de su cultura era un camino a seguir. Este hecho lo demostraron fehacientemente los Incas.

Figura 2. Ubicación del Coricancha (3) en el Hurin Cusco en relación con otros edificios incas.

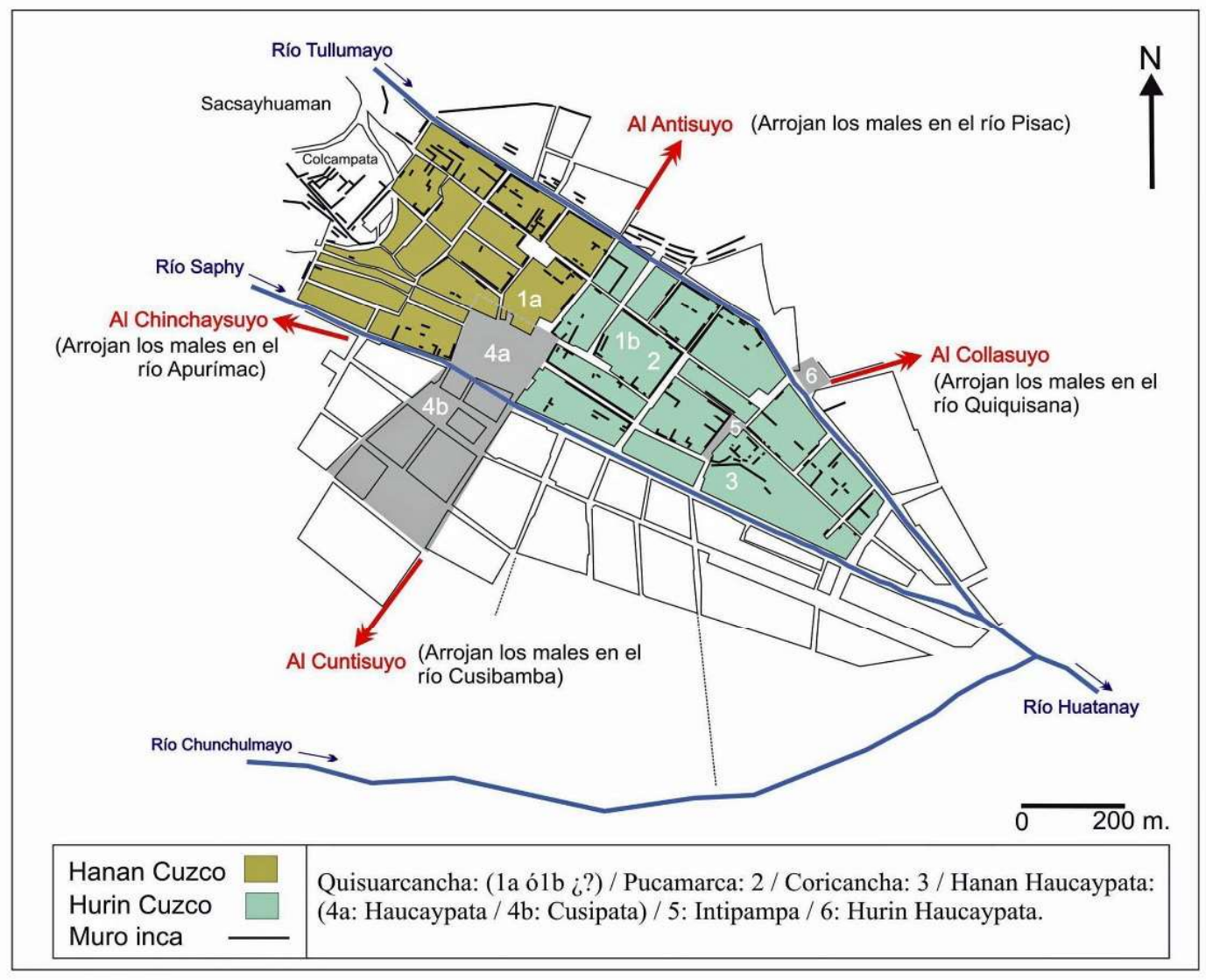

Fuente: Plano de Rodolfo Monteverde. Rodolfo Monteverde, "Los incas y la fiesta de La Situa", Chungará (Arica) 43, no. 2. (2011): 243253. DOI: https://dx.doi.org/10.4067/S0717-73562011000200006.

13 Luis Millones, "Los dioses de Santa Cruz (Comentarios a la crónica de Juan de Santa Cruz Pachacuti Yamqui Salcamaygua)", Revista de Indias 30, no. 123 (1979); Rita Fink, "La cosmología en el dibujo del altar del Quri Kan e ha según don Joan de Santa Cruz Pachacuti Yamqui Salea Maygua" Histórica 25, no. 1 (2001): 9-75. 
En el Tahantinsuyo, el inca Pachacútec y su sucesor Túpac Inca Yupanqui ${ }^{14}$, quien asumió su mandato en el mismo Coricancha según relato de Miguel Cabello de Balboa $^{15}$, implementaron una política pública de mantener los espacios ceremoniales de los territorios conquistados; buscaron reutilizar estos espacios, para después superponer y situar lo simbólicamente incaico con la tradición o huaca local. Esto es, jerarquizar desde los aspectos cosmogónicos las disposiciones arquitectónicas donde un contundente ejemplo es el Templo del Sol en Pachacamac.

Figura 3. Plano del Templo y Convento del Sol, Cusco.

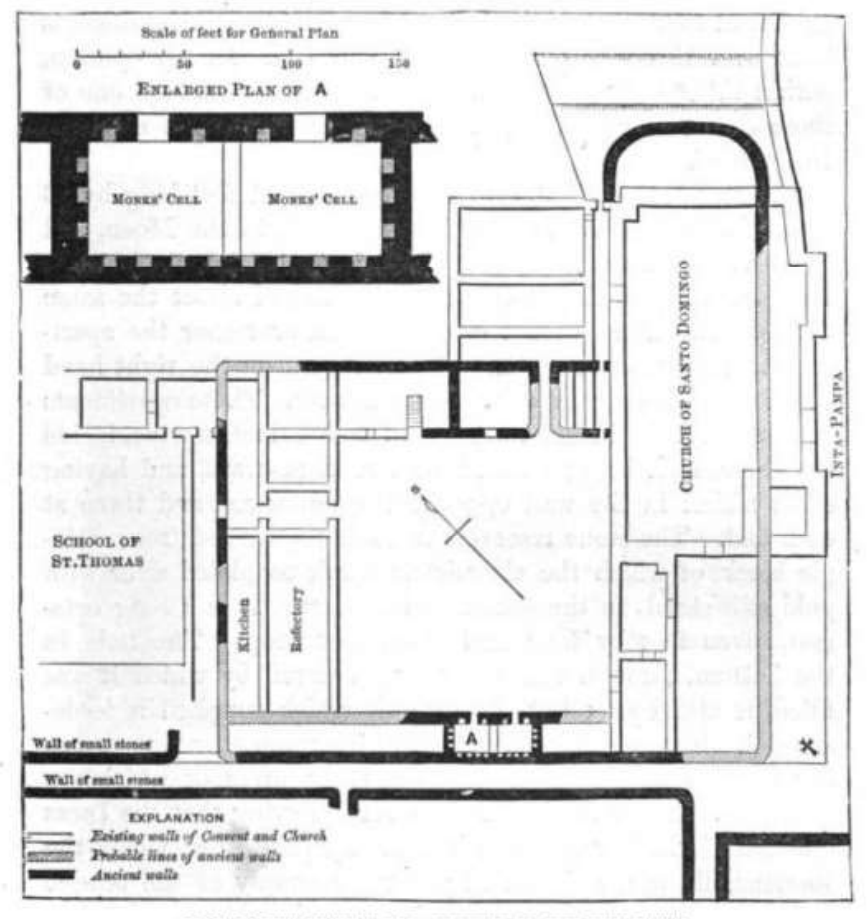

PLAN OF THK TEMPLE AND CONVENT OF THE SUN, CUZCO.

Fuente: Plano registrado por Squier. Squier, Ephraim. Peru: Incidents of Travel and Exploration in the Land of the Incas. Macmillan and Company, 1877.

14 "Atribuyen el edificio de aquel templo al Rey Inca Yupanqui, abuelo de Huayna Cápac, no porque él lo fundase, que desde el primer Inca quedó fundado, sino porque lo acabó de adornar y poner en la riqueza y majestad que los españoles lo hallaron". Garcilaso de la Vega, Comentarios Reales de los Incas.

15 “... el viejo Yngayupanqui en presencia de sus estatuas, y Ydolos del Ticciviracocha Pachacama y de toda la nobleza del Ymperio, en el Templo del Curicancha renunció el Reyno en su hijo Topa Yngayupanqui, y con grandísimas ceremonias, y bendiciones le fue dado el cetro, o Topayauri, y vestida la vestidura Torcogualca y adornada su cabeza con la borla Sunturpaucar, y fueron puestas en sus pies las Sandalias (a quien ellos, llamauan Oxotas) y con tal adorno fue adorado de el Pueblo, y los Capitanes Señores y Cortesanos le besaron los pies...”. Miguel Cabello de Balboa, Miscelánea Antártica: una historia del Perú antiguo [1586] (Lima: UNMSM. Instituto de Etnología, 1951), 333. https://idoc.pub/ documents/miscelanea-antartica-miguel-cabello-de-balboapdf-klzzlovv8elg. 
El inca Pachacútec creó esta política y, por su parte, Túpac Yupanqui la mejoró y engrandeció lugares ceremoniales; en este caso invirtió recursos para mejorar el $\mathrm{Pu}$ quin Cancha, que era el lugar sagrado donde los ancestros incas reposaban con funciones y resultados ideológicos ${ }^{16}$. Desafortunadamente, la visión totalitarista del virrey Toledo terminó destruyendo y saqueando estos lugares ceremoniales prehispánicos $\mathrm{y}$, bajo el mismo principio alejandrino de conquistar, saquear y poseer trofeos de guerra, la gestión virreinal de Francisco Toledo envió objetos del Coricancha al rey de España.

El cronista Pedro Sarmiento de Gamboa es un testigo de este suceso ${ }^{17}$, narrando que en el Puquin Cancha, nombrado por él mismo como Quinticancha y Kiricancha, se custodiaban con sigilo y exhibían solemnemente los inmensos paños y tablones pintados, quipus - que fueron quemados - entre otros artefactos como las yupanas o maquetas de edificios incas, o la huaca litificada Rocromuca junto al edificio del Coricancha ${ }^{18}$. Asimismo, señala que los quipus sirvieron como un registro de las hazañas heroicas de los ancestros incas. En resumen, tenemos que resaltar la importante carga museística que tuvo el Coricancha, el cual trascendió como un artefacto de poder que educó, controló y fue referencia sustancial para especialistas como los amautas y los quipucamayocs. El ser un espacio restringido para ciertas jerarquías fue vital, pero lo más importante es que su carga simbólica no fue solo prehispánica, sino también colonial; si bien existió una destrucción del interior, este espacio fue reutilizado por la Iglesia; si en el período prehispánico fue un centro de culto a los dioses andinos, ahora se había transformado en un espacio de culto del Dios cristiano, que fue el vencedor de la contienda.

Algunos de los objetos del Coricancha fueron enviados a España, entre estos destacaría el Punchao, un ídolo o huaca de primer orden para el Estado inca. El valor del Punchao también radicó en la idea que este contenía cenizas de los corazones de los jerarcas incas ${ }^{19}$. Este objeto fue trasladado por las huestes de Manco Inca para ser

16 "Volviendo a nuestra historia, decimos que por sola aquella pieza que cupo de parte a un español, se podrá sacar el tesoro que en aquella ciudad y su templo hallaron los españoles. A un lado y a otro de la imagen del Sol estaban los cuerpos de los Reyes muertos, puestos por su antigüedad, como hijos de ese Sol, embalsamados, que (no se sabe cómo) parecían estar vivos. Estaban asentados en sus sillas de oro, puestas sobre los tablones de oro en que solían asentarse. Tenían los rostros hacia el pueblo; solo Huayna Cápac se aventajaba de los demás, que estaba puesto delante de la figura del Sol, vuelto el rostro hacia él, como hijo más querido y amado, por haberse aventajado de los demás, pues mereció que en vida le adorasen por Dios por las virtudes y ornamentos reales que mostró desde muy mozo. Estos cuerpos escondieron los indios con el demás tesoro, que los más de ellos no han parecido hasta hoy. El año de 1559 el Licenciado Polo descubrió cinco de ellos, tres de Reyes y dos de Reinas". Garcilaso de la Vega, Comentarios Reales de los Incas.

17 Pedro Sarmiento de Gamboa, Historia de los Incas [1572] (Biblioteca virtual Miguel de Cervantes: 1988), 61.

18 Este nombre corresponde a Rocromuca de la lista de guacas ( $\mathrm{Cu}-7: 2)$ : "una piedra grande que estatua junto al templo del sol". John Rowe, "Probanza de los incas nietos de conquistadores", Histórica 9, no. 2 (1985a): 241.

19 Bernabé Cobo, Historia del nuevo mundo, vol. 1 (Sevilla: Imp. de E. Rasco, 1890). 
oculto en Vilcabamba por 40 años, hasta la captura de Túpac Amaru I y su decapitación por orden de virrey Toledo, en la plaza Hawkaypata del Cusco, un 24 de setiembre de 1572 .

En ese mismo año, el virrey Toledo envió el Punchau al rey Felipe II de España, y en cartas sucesivas le recomendaba que le obsequiara el ídolo inca al pontífice Gregorio XIII, esto por ser "el más grande ídolo de oro fino que adoraban los infieles peruanos, y por su causa les hacían guerras" ${ }^{20}$.

\section{Un espacio sagrado y un [proto] museo inca}

No solo el Coricancha puede ser pensado como un proto museo. Creemos que el Yachaywasi ${ }^{21}$ merece un amplio estudio porque en este espacio se atesoraron y custodiaron colecciones de diversos objetos con el fin de educar a la nobleza cusqueña, tanto en lo político como en el conocimiento de mitos, ritos, historia, geopolítica y toda la gama de conocimientos que resultasen importantes para ejercer el poder desde un expansionista Estado incaico. Por ejemplo, Kosiba y Galiano presentan una data arqueológica para establecer que el desarrollo y construcción del paisaje inca en Cusco remata y resuelve la reutilización de espacios o lugares ceremoniales preexistentes, en tanto que no haya sido una ocupación puramente militar para destruirlos, sino para adaptar y adoptar al ídolo o a la huaca lugareña como costumbres y como mecanismo transformador para afianzar la autoridad inca ${ }^{22}$.

Aunque los casos expuestos por Kosiba y Galiano son de Wat'a, Pumamarca y Ollantaytambo, existe una constante ideológica: la reconversión de los lugares sagrados. Esta propuesta nos permite hacerla extensiva al Coricancha y así tratar de comprender que siempre tuvo ese carácter sagrado y que, incluso, fue la última morada

$20 \quad$ Garcilaso de la Vega, Comentarios Reales de los Incas.

21 "Para decir los barrios que quedan, me conviene volver al barrio Huacapuncu, que es puerta del santuario, que estaba al norte de la plaza principal de la ciudad, al cual se le seguía, yendo al mediodía, otro barrio grandísimo, cuyo nombre se me ha olvidado; podrémosle llamar el barrio de las escuelas, porque en él estaban las que fundó el Rey Inca Roca, como en su vida dijimos. En indio dicen Yacha Huaci, que es casa de enseñanza. Vivían en él los sabios y maestros de aquella república, llamados amauta, que es filósofo, y haráuec, que es poeta, los cuales eran muy estimados de los Incas y de todo su Imperio. Tenían consigo muchos de sus discípulos, principalmente los que eran de la sangre real. Yendo del barrio de las escuelas al mediodía, están dos barrios, donde había dos casas reales que salían a la plaza principal. Tomaban todo el lienzo de la plaza; la una de ellas, que estaba al levante de la otra, se decía Coracora; quiere decir: herbazales, porque aquel sitio era un gran herbazal y la plaza que está delante era un tremedal o cenagal, y los Incas mandaron ponerla como está. Lo mismo dice Pedro de Cieza, capítulo noventa y dos. En aquel herbazal fundó el Rey Inca Roca su casa real, por favorecer las escuelas, yendo muchas veces a ellas a oír los maestros". Garcilaso de la Vega, Comentarios Reales de los Incas.

22 Steve Kosiba y Vicentina Galiano, "Construyendo un Paisaje Inka: La conversión de los Centros Ceremoniales y la constitución de la autoridad durante la Formación del Estado Inkaiko (Cusco, Perú)", Arqueología y Sociedad 26 (2013): 301-38. 
de las momias incas, las cuales eran consideradas como ídolos o huacas asociadas a la narrativa mítica y heroica del expansionista Estado. De esta forma, superpusieron - menguando lo preincaico - la autoridad simbólica en el diseño y el ejercicio del paisaje social cusqueño. Este aspecto ya fue expresado por Rodolfo Monteverde ${ }^{23}$, quien, al estudiar la celebración inca de La Situa, rescata la hegemonía y polifuncionalidad del edificio, en donde el mismo gobernante incaico dirigía el evento político y simbólico con jerarquizados grupos sociales que peregrinaban al Hurin Cusco con sus huacas e ídolos (ver figura 2). La dimensión física de La Situa tiene componentes etnográficos que se desarrollan en el hoy llamado Cusco monumental, precisamente en el Coricancha, donde, por ejemplo, las imágenes de Viracocha Pachayachachic y Chuquilla, según Cristóbal de Molina, eran llevadas al Coricancha y, durante el tiempo de fiesta, se les ofrendaba ${ }^{24}$. El dato etnohistórico revela cierto proceso y cierta estructura de acopio de ofrendas de huacas e ídolos de todo el Tahuantinsuyo dentro del Coricancha.

Es así que el Coricancha sería también un marcador ancestral en términos político-ideológicos. Juan de Betanzos, en la tabla de los Yngas, alude a propias formas de parentesco tanto sanguíneas como de alianzas, que rememoran a ancestros comunes ${ }^{25}$. En estos casos existió un sistema propio sobre la jerarquía simbólica de las momias incas en función a su prestigio. Asimismo, es importante resaltar que tanto de los objetos expuestos, como de las grandes láminas de oro y plata con escenas míticas y representaciones de deidades ${ }^{26}$, existe la predominante intención de musealizar ciertos ídolos e imágenes en un espacio de diálogo. Por consiguiente, se tiene como fin el dualizar la interacción especialista-aprendiz y especialista-político entre amautas y estudiantes, entre quipucamayocs y militares, entre hacedores de yupanas y representantes de panacas, entre especialistas y el qhapaq ayllu ${ }^{27}$.

23 Monteverde, "Los incas y la fiesta de La Situa".

24 Citado en Rodolfo Monteverde, "Los incas y la fiesta de La Situa".

25 Luis Arana Bustamante, "Sobre el significado de Yupanqui en referencia al título de los Ancestros Reales de los Inka", Arqueología y Sociedad 31 (2016): 245-254.

26 "Había un gran maizal y la semilla que llaman quinua y otras legumbres y árboles frutales, con su fruta toda de oro y plata, contrahecho al natural. Había también en la casa rimeros de leña contrahecha de oro y plata, como los había en la casa real; también había grandes figuras de hombres y mujeres y niños, vaciados de lo mismo, y muchos graneros y trojes, que llaman pirua, todo para ornato y mayor majestad de la casa de su Dios el Sol. Que, como cada año, a todas las fiestas principales que le hacían le presentaban tanta plata y oro, lo empleaban todo en adornar su casa inventando cada día nuevas grandezas, porque todos los plateros que había dedicados para el servicio del Sol no entendían en otra cosa sino hacer y contrahacer las cosas dichas. Hacían infinita vajilla, que el templo tenía para su servido hasta ollas, cántaros, tinajas y tinajones. En suma, no había en aquella casa cosa alguna de que echar mano para cualquier ministerio que todo no fuese de oro y plata, hasta lo que servía de azadas y azadillas para limpiar los jardines. De donde con mucha razón y propiedad llamaron al templo del Sol y a toda la casa Coricancha, que quiere decir barrio de oro". Garcilaso de la Vega, Comentarios Reales de los Incas.

Rowe, "La constitución inca del Cuzco". 


\section{Conclusiones}

En efecto, en el contexto inca existieron artefactos de poder específicos, como su fuerza militar. Sin embargo, se hallaron cargas ideológicas y simbólicas que se plasmaron en la arquitectura y la disposición de estas en los territorios conquistados por los incas, principalmente en el Cusco.

De esta forma, un artefacto de poder, expresado en la teoría de dispositivo/diferencia de Zamorano y Rogel $^{28}$, se hace visible en el propio Coricancha durante el período Inca debido a que este artefacto de poder - aun considerando su carga museística y que fuera un lugar simbólico y sagrado para los vencidos cusqueños - fue destruido por la administración española para crear otro, re funcionalizando al Coricancha como un artefacto de poder de mayor prestancia religiosa para un efectivo control social. En ambos casos, tanto en el período Inca como en el virreinal, se aprecian las relaciones de poder, subalternidades y jerarquías (ver figuras 1 y 2), atribuyéndosele a este edificio principal una genealogía e indicador de poder.

Las cargas discursivas de cronistas formalizan una semántica que visibiliza el saber y el poder de un lugar sagrado principal como el Coricancha. En ese sentido, la proyección continuista del Coricancha, validando su ropaje tahuantinsuyano andino y su catolicismo andino, se recreó como artefacto de poder fortaleciendo sus características museísticas.

Por lo tanto, por la evidencia presentada, el Coricancha fue un artefacto de poder categórico que tendría solo comparación con el oráculo de Pachacamac, toda vez que existió como la preforma de un auténtico museo o, dicho de otro modo, una institución museística de primer orden. Ironías de la historia: hoy sigue siendo espacio sagrado y un importante museo.

\section{Bibliografía y fuentes primarias}

Arana Bustamante, Luis. "Sobre el significado de Yupanqui en referencia al título de los Ancestros Reales de los Inka”. Arqueología y Sociedad 31 (2016): 245-254.

Ballart, Josep y Jordi Juan i Tresserras. Gestión del patrimonio cultural. Barcelona: Editorial Ariel: 2001.

Betanzos, Juan D. Suma y narración de los Incas. Madrid: Biblioteca Hispano-Ultramarina, 1880. 
Bobadilla, Luis, Camilo Cammás y Nicole Solis. Madrid, "Aproximaciones al derecho de los conflictos armados: de los trofeos e indemnizaciones de guerra", tesis de licenciatura, Universidad de Chile, 2001. http://repositorio.uchile.cl/ handle/2250/111043.

Cabello de Balboa, Miguel. Miscelánea Antártica: una historia del Perú antiguo [1586]. Lima: UNMSM, Instituto de Etnología, 1951. https://idoc.pub/documents/miscelanea-antartica-miguel-cabello-de-balboapdf-klzzlovv8elg.

Cieza de León, Pedro. Crónica del Perú. El señorío de los Incas. Caracas: Biblioteca Ayacucho, 2005. http://www.biblioteca.org.ar/libros/211665.pdf.

Cobo, Bernabé. Historia del nuevo mundo. Vol. 1. Sevilla: Imp. de E. Rasco, 1890.

Elías, José. "El dibujo del Altar Mayor del Coricancha”. Arte y Diseño A\&D 2 (2013): 14-18.

Fink, Rita. "La cosmología en el dibujo del altar del Quri Kan e ha según don Joan de Santa Cruz Pachacuti Yamqui Salea Maygua". Histórica 25, no. 1 (2001): 9-75.

Garcilaso de la Vega. Comentarios Reales de los Incas. Lisboa: Princeps de Lisboa, 1609. http://shemer.mslib.huji.ac.il/lib/W/ebooks/001531300.pdf.

Kosiba, Steve y Vicentina Galiano. "Construyendo un Paisaje Inka: La conversión de los Centros Ceremoniales y la constitución de la autoridad durante la Formación del Estado Inkaiko (Cusco, Perú)". Arqueología y Sociedad 26 (2013): $301-38$.

Millones, Luis. "Los dioses de Santa Cruz (Comentarios a la crónica de Juan de Santa Cruz Pachacuti Yamqui Salcamaygua)”. Revista de Indias 30, no. 123 (1979).

Monteverde, Rodolfo. "Los incas y la fiesta de La Situa". Chungará (Arica) 43, no. 2. (2011):243-253. DOI: https://dx.doi.org/10.4067/S0717-73562011000200006.

Murúa, Martín D. Historia general del Perú. Origen y descendencia de los Incas [1616]. Madrid: Imp. De don Arturo Góngora. 1962.

Pachacuti, Juan Santa Cruz. Relación de Antigüedades de este del reino del Pirú [1613]. Biblioteca Nacional de España, 1995. http://www.bne.es/es/Activida- 
des/Exposiciones/Exposiciones/exposiciones2016/BibliotecaIncaGarcilaso/ Seleccion/obra09.html.

Pérez Mateo, Soledad. "La educación en los museos universitarios". Boletín de arte 25 (2018): 491-518.

Rowe, John. "La constitución inca del Cuzco". Histórica 9, no. 1 (1985): 35-73.

—. "Probanza de los incas nietos de conquistadores". Histórica 9, no. 2 (1985a): 193-245.

Sarmiento de Gamboa, Pedro. Historia de los Incas [1572]. Biblioteca virtual Miguel de Cervantes: 1988.

Squier, Ephraim. Peru: Incidents of Travel and Exploration in the Land of the Incas. Macmillan and Company, 1877.

Wernke, Steven. "La producción de poder en el entorno construido a través de la invasión española, valle del Colca (Perú)". Boletín de Arqueología PUCP 20 (2016): 149-166.

Zamorano, Raúl y Rosario Rogel. "El dispositivo de poder como medio de comunicación: Foucault-Luhmann". Política y Sociedad 50, no. 3 (2013): 959-980. 